DOROTA MURZYN

Uniwersytet Pedagogiczny, Kraków, Polska

\title{
Wpływ wykorzystania funduszy strukturalnych w Małopolsce na rozwój sieci wspólpracy i innowacyjność regionu
}

\author{
The Impact of Structural Funds in Malopolska \\ for the Development of Networks and Regional Innovation
}

Streszczenie: Celem artykułu jest przedstawienie różnych koncepcji łączących zagadnienia sieci współpracy i innowacyjność na poziomie regionalnym (model potrójnej helisy, klastry, systemy innowacji) oraz próba zbadania, w jaki sposób wykorzystanie funduszy strukturalnych Unii Europejskiej wpływa na ich rozwój w Małopolsce.

Władze regionalne, przedsiębiorstwa i uczelnie wyższe Małopolski zdają się dostrzegać szanse, jakie niesie ze sobą tworzenie sieci współpracy. Coraz częściej i chętniej współpracują ze sobą, wpływając tym samym na innowacyjność regionu oraz na budowanie gospodarki opartej na wiedzy. Koncepcja trójstronnej współpracy na rzecz kreowania środowiska odpowiedniego dla wzrostu innowacyjności i konkurencyjności uwzględniona została w najważniejszych dokumentach strategicznych województwa.

Fundusze strukturalne Unii Europejskiej są istotnym czynnikiem wspierania sieci współpracy w regionie małopolskim. Zostały wskazane jako podstawowe źródła finansowania celów Regionalnej Strategii Innowacji Województwa Małopolskiego 2008-2013. Są także ważnym źródłem wsparcia rozwoju powiązań w ramach potrójnej helisy i klastrów.

Sprawnie funkcjonująca sieć powiązań i współpracy między władzą publiczną, jednostkami naukowymi i przedsiębiorstwami jest niezbędna, aby stworzyć region wiedzy i innowacji. Taka struktura, wspierana finansowo z różnych źródeł, w tym funduszy strukturalnych UE, ma szanse stania się obszarem innowacyjnym i konkurencyjnym.

\footnotetext{
Abstract: This article aims to present different concepts linking issues of networks and innovation at the regional level (triple helix model, clusters, innovation systems) and attempt to examine how the use of European Union structural funds affect their development in Małopolska region.

The regional authorities, companies and universities of Małopolska seem to recognize opportunities offered by the establishment of networks. They are gradually more likely and willing to cooperate with each other, thereby affecting innovation in the region and building a knowledge-based economy.The concept of trilateral cooperation for the creation of a suitable environment for the growth of innovation and competitiveness has been included in major policy documents in the region.
} 
EU structural funds are an important factor in the promotion of regional networks in Małopolska. They have been identified as the primary source of financing objectives of the Regional Innovation Strategy of the Małopolska Region 2008-2013. They are also an important source of support for the development of relations in the triple helix and clusters.

A well-functioning network of relations and cooperation between public authorities, scientific institutions and enterprises is essential to create a region of knowledge and innovation. Such a structure, supported by alternative sources of funding, including EU structural funds, has a chance to succeed and become an innovative and competitive area.

Słowa kluczowe: fundusze strukturalne UE; gospodarka oparta na wiedzy; innowacyjność; polityka regionalna; sieci współpracy

Key words: collaborative networks; EU structural funds; innovation regional policy; knowledge-based economy

\section{WPROWADZENIE}

Ważną cechą gospodarki opartej na wiedzy jest innowacyjność. Procesy innowacyjne i ich wykorzystanie mają niezwykle istotne znaczenie dla rozwoju gospodarczego. Szczególnie na poziomie regionalnym znaczenia nabiera umiejętność właściwego rozpoznania i spożytkowania endogenicznych zasobów w tym zakresie.

Procesy dyfuzji wiedzy o charakterze wewnątrzregionalnym zachodzą w sytuacji, gdy aktorzy zaangażowani w proces kształtowania innowacji (np. jednostki naukowe, przedsiębiorstwa, sektor rządowy) nawiązują ścisłe relacje prowadzące do osiągnięcia efektu sprzężenia zwrotnego w obrębie regionalnych systemów innowacji. Interakcji pomiędzy światem biznesu, nauki i administracji dotyczą także model potrójnej helisy i koncepcja klastrów. Celem artykułu jest przedstawienie tych różnych koncepcji łączących zagadnienia sieci współpracy i innowacyjność na poziomie regionalnym. Koncepcje te nie wykluczają się, a ich zbieżne założenia znajdują szczególne odzwierciedlenie w polityce regionalnej realizowanej przez Unię Europejską. Instrumenty tej polityki służą szeroko rozumianemu rozwojowi regionów europejskich, wspierają także rozwój powiązań kooperacyjnych w regionach. Działania te mają szansę poprawić sytuację polskich regionów w zakresie innowacyjności. Autorka artykułu pragnie pokazać wykorzystanie tych możliwości w województwie małopolskim.

\section{INNOWACYJNOŚĆ POLSKICH REGIONÓW}

Innowacyjność można odnieść do całego kraju, jego części składowych (regionów), organizacji (w tym przedsiębiorstw) lub do pojedynczych ludzi. Istnieją przy tym różne wskaźniki wykorzystywane do pomiaru innowacyjności gospodarki (Nowak, 2012). Innowacyjność regionu należy rozumieć jako „zdolność całego układu społecznego, gospo- 
darczego i instytucjonalnego do tworzenia, absorpcji i rozprzestrzeniania innowacji" (Olechnicka, 2007: 55). Poziom innowacyjności decyduje o konkurencyjności gospodarek regionalnych, przy czym wpływ ten jest największy w przypadku regionów określanych jako źródła wiedzy (Golejewska, 2012).

Sytuację polskich regionów na tle regionów UE zobrazować można za pomocą Regionalnego Indeksu Innowacyjności (Hollanders i in., 2009). Szereguje on regiony od najmniej (low innovators) do najbardziej innowacyjnych (high innovators). Polskie regiony sklasyfikowane są na końcu rankingu (low i medium-low innovators).

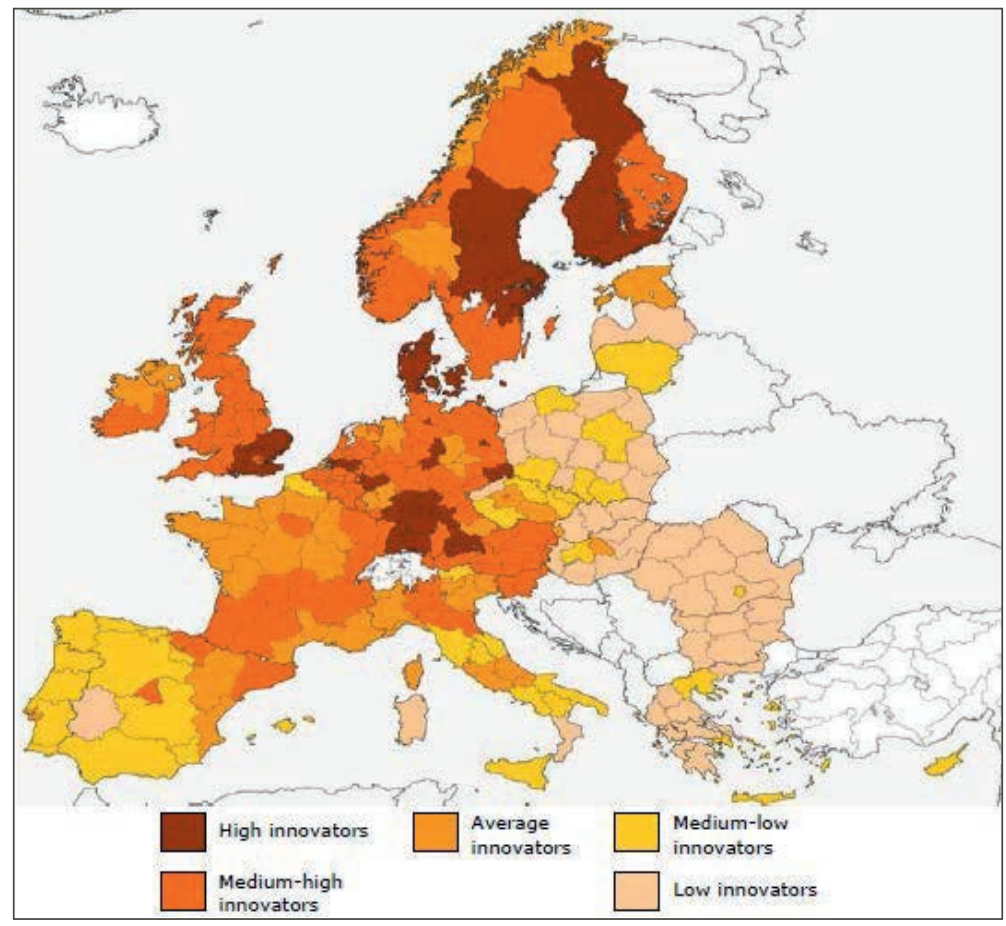

Ryc. 1. Regionalny Indeks Innowacyjności 2009

Źródło: Hollanders, Tarantola, Loschky, 2009; Regional Innovation Scoreboard (RIS) 2009: 3

Najczęściej analizowanym wskaźnikiem innowacyjności jest wielkość (i struktura) nakładów na działalność badawczo-rozwojową. W Polsce wskaźnik ten przyjmuje alarmująco niski poziom, zarówno w wielkościach bezwzględnych, jak i w relacji do PKB czy liczby mieszkańców. Od 2002 r. wskaźnik udziału nakładów na B+R w PKB kształtuje się na poziomie ok. 0,56\%, co stanowi 30\% średniej unijnej. Występują przy tym istotne i trwałe różnice w potencjale innowacyjnym poszczególnych województw - ponad 50\% wydatków na $\mathrm{B}+\mathrm{R}$ koncentruje się w dwóch polskich województwach: mazowieckim i małopolskim, podczas gdy nakłady ponoszone w województwach świętokrzyskim, opolskim, podlaskim, lubuskim, warmińsko-mazurskim czy zachodniopomorskim mają charakter marginalny (ryc. 2). 


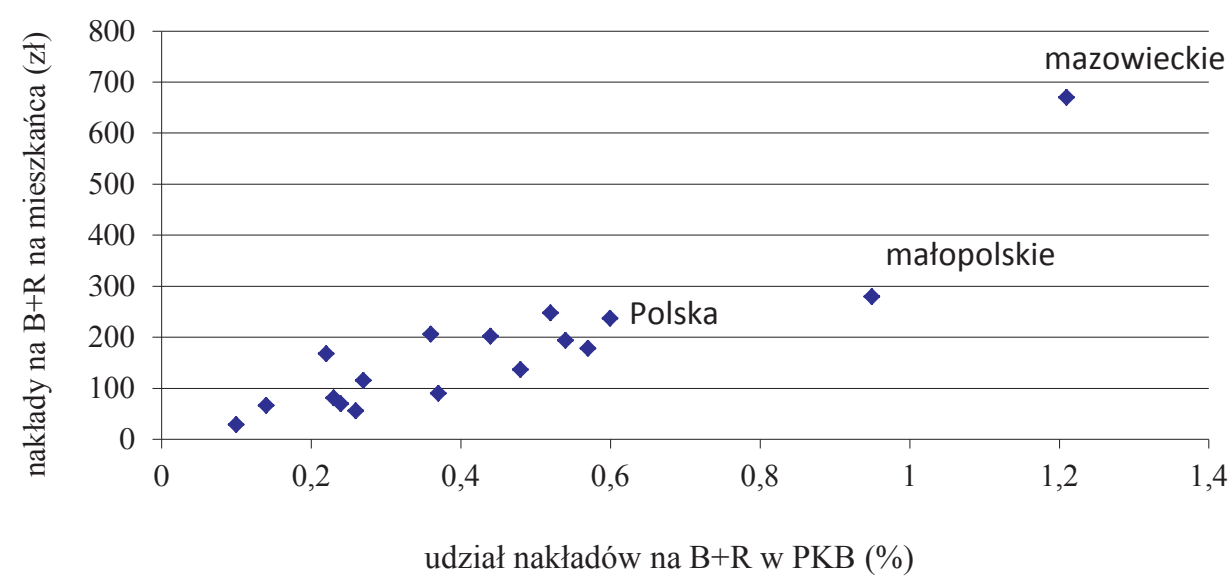

Ryc. 2. Nakłady na B+R w województwach Polski w 2009 r.

Źródło: opracowanie własne na podstawie danych GUS 2011

Stopień zróżnicowania innowacyjności regionów można także badać pod względem zatrudnienia, biorąc pod uwagę: udział zatrudnionych w przemyśle wysokich i średnich technologii w ogólnej liczbie pracujących, udział zatrudnionych w „wiedzochłonnych” usługach w ogólnej liczbie pracujących, udział personelu sektora B+R w ogólnej liczbie pracujących czy konstruując mierniki syntetyczne (Borowiec, Dorocki, Jenner, 2009). Kluczową rolę w budowaniu innowacyjności regionów odgrywa także sfera własności intelektualnej (Gierańczyk, 2010).

Czy sytuację w zakresie innowacyjności w regionach mogą zmienić tworzące się w nich sieci współpracy? W dalszej części artykułu przedstawione zostaną koncepcje obrazujące interakcje pomiędzy światem biznesu, nauki i administracji w regionie.

Model POTRÓJNEJ HELISY (ANG. TRIPLE HELIX)

Relacje pomiędzy przedsiębiorstwami, władzą publiczną i uniwersytetami wyjaśnia model potrójnej helisy. W modelu tym kluczową rolę w kreowaniu działalności innowacyjnej odgrywają uniwersytety. Koncepcja ta nawiązuje do zmieniającej się roli sektora nauki w rozwoju i wynikających z tego nowych interakcji z otoczeniem.

Model potrójnej helisy zakłada istnienie infrastruktury wiedzy, w której strefy instytucjonalne zachodzą na siebie, funkcje przez nie pełnione przenikają się, a wewnątrz obszaru wzajemnego oddziaływania wyłaniają się organizacje o charakterze hybrydowym (Etzkowitz, Leydesdorff, 2000: 111), tak jak to przedstawiono na ryc. 3. 


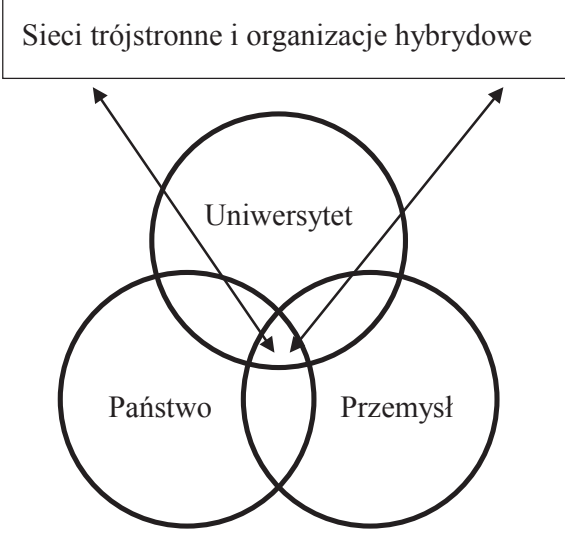

Ryc. 3. Model potrójnej helisy przedstawiający relacje pomiędzy uniwersytetem, działalnością przemysłową i władzą publiczną

Źródło: Etzkowitz, Leydesdorff (2000), s. 111

Zakresy działania instytucji z tych trzech sfer: nauki, biznesu, władzy, wzajemnie się przenikają, dlatego instytucje te mogą odgrywać role przypisane do innego sektora. Uniwersytety zaczynają być przedsiębiorcze (Clark, 1998), przedsiębiorstwa natomiast rozwijają funkcje naukowe. Tworzenie środowiska innowacyjnego może być inicjowane przez władze regionalne, które określają jego reguły funkcjonowania, ale nie kontrolują wspólnych przedsięwzięć.

Współdziałanie pomiędzy sferą nauki a przedsiębiorstwami i administracją prowadzi do tego, że uczelnie wyższe kształcą odpowiednie kadry i realizują badania, których wyniki mogą zostać zastosowane przez przedsiębiorstwa, administracja natomiast stara się lepiej dostosowywać swoje działania do potrzeb tych przedsiębiorstw, np. rozbudowując niezbędną infrastrukturę czy współfinansując badania naukowe.

\section{KLASTRY}

Skutecznym sposobem dążenia do osiągnięcia efektów synergii wynikających ze współpracy poszczególnych podmiotów wchodzących w skład tzw. potrójnej helisy, a więc przedsiębiorców, przedstawiciel nauki i władz publicznych, może być tworzenie klastrów. Stanowią one jeden ze sposobów stymulowania współpracy między jednostkami naukowymi prowadzącymi prace badawczo-rozwojowe, przedsiębiorstwami wykorzystującymi wyniki tych prac oraz instytucjami otoczenia biznesu, wspierającymi komercjalizację wiedzy. Przez klaster rozumie się przestrzennie skoncentrowaną grupę wzajemnie powiązanych firm, wyspecjalizowanych dostawców, jednostek świadczących usługi, firm działających w pokrewnych sektorach i związanych z nimi instytucji (np. uniwersytetów, stowarzyszeń branżowych) w poszczególnych dziedzinach, konkurujących między sobą, ale również współpracujących 
(Porter, 2001: 248). Klastry to sektorowe i przestrzenne koncentracje firm produkujących i sprzedających podobne lub komplementarne produkty, a przez to zmuszonych do przezwyciężania podobnych problemów i wyzwań (Ceglie i Dini, 1999: 2). Charakterystyczną cechą klastrów przemysłowych jest to, że przedsiębiorstwa w nich skupione konkurują ze sobą, ale jednocześnie współpracują w tych obszarach, gdzie możliwe jest wyzwolenie efektów synergicznych (wspólne prace badawczo-rozwojowe, dyfuzja know-how, skupienie zasobów, otwartość na innowacje i zdolność ich absorpcji, przyciąganie nowych zasobów i przedsiębiorstw, redukcja ryzyka). Konkurencja nie wyklucza wzajemnych, korzystnych interakcji z innymi firmami, a może stać się motorem ich rozwoju (ang: co-opetition - od cooperation i competition).

Klastry należy odróżnić od tzw. inicjatywy klastrowej. Inicjatywa klastrowa to celowe działanie ukierunkowane na budowę sformalizowanej struktury wspomagającej współpracę między poszczególnymi uczestnikami klastra lub jego zalążka zainicjowanych spontanicznie (Kładź, Kowalski, 2010: 264). Inicjatywy klastrowe stanowią zorganizowane działania mające na celu przyspieszenie rozwoju oraz wzrostu konkurencyjności klastrów w regionie, obejmujące firmy funkcjonujące w ramach klastra, rząd oraz środowisko badawcze (Sölvell i in., 2006).

Podmiotami wchodzącymi w skład klastrów są przedsiębiorstwa (klastry reprezentują model działalności biznesowej, opartej na kooperacji mimo konkurencji), jednostki naukowe (klastry stanowią nowy model interakcji między nauką a gospodarką) i władze publiczne. Te ostatnie odgrywają istotną rolę w kształtowaniu polityki rozwoju gospodarczego opartej na klastrach (ang. cluster-based economic development policy). Koncepcja ta w ostatnich latach jest szczególnie rozwijana przez OECD. Klastry mogą być fundamentem rozwoju regionalnego. Są one nie tylko sposobem rozwoju pojedynczych przedsiębiorstw, ale pozwalają na stworzenie sieci współpracy, których siła oddziaływania wykracza poza środowiska lokalne. W ramach polityki klastrowej uruchamiane są różnorodne działania mające na celu stymulowanie rozwoju regionalnego przez wspieranie konkurencyjności podmiotów gospodarczych.

Rosnące znaczenie i popularność koncepcji klastra znalazły wyraz w polityce Unii Europejskiej. UE przyjęła w 2006 r. szeroko zakrojoną strategię innowacyjną oraz wskazała wzmacnianie klastrów w Europie jako jeden ze strategicznych priorytetów skutecznego promowania innowacji (Komisja Europejska, 2006). Polityka wspierania klastrów stała się ważnym elementem polityki innowacyjnej państw członkowskich, wspomagana jest przez instrumenty wspólnotowe. Szczególnie europejska polityka regionalna na lata 2007-2013 zakłada podejście oparte na regionalnych klastrach innowacyjnych. Właśnie na poziomie regionalnym wiele firm, zwłaszcza MŚP, współpracuje ze sobą i z ośrodkami naukowymi i technologicznymi. Sąsiedztwo jest zatem kluczowym elementem procesu innowacji i zwiększa skuteczność polityki innowacyjnej, w przypadku dostosowania do potrzeb regionalnych i lokalnych. Wiele badań potwierdza, że przedsiębiorstwa uczestniczące w klastrach są bardziej innowacyjne, uzyskują więcej patentów i znaków towarowych niż inne innowacyjne przedsiębiorstwa (Komisja Europejska, 2008). 
W Polsce konieczność wspierania rozwoju klastrów została zauważona w dokumencie przyjętym przez Radę Ministrów w 2006 r.: Kierunki zwiększania innowacyjności gospodarki na lata 2007-2013. Podkreślono w nim znaczenie wspierania współpracy przedsiębiorstw o charakterze sieciowym, ukierunkowanej na realizację innowacyjnych przedsięwzięć (Ministerstwo Gospodarki, 2006). Uznaje się, że klastry to jedna z najefektywniejszych form działalności, posiadająca wymiar lokalny i ponadregionalny (Klamut, 2011).

\section{SYSTEMY INNOWACJI}

Obecnie coraz bardziej zyskuje na znaczeniu postrzeganie innowacji jako systemu. Koncepcja systemów innowacji stanowi wyższe stadium rozwoju koncepcji sieci innowacyjnych i klastrów (Pachura, 2009). W podejściu mówiącym o systemach innowacji (Lundvall, 1992; Nelson, 1993) analizuje się wpływ szeroko rozumianych instytucji zewnętrznych na działalność innowacyjną firm i innych uczestników procesu. Podkreśla się rolę transferu oraz dyfuzji wiedzy i technologii. Innowacje postrzegane są jako proces dynamiczny, w którym wiedza akumuluje się w procesach uczenia się i interakcji. Systemowe koncepcje innowacji przesuwają punkt ciężkości polityki publicznej ku wzajemnym oddziaływaniom instytucji oraz skupiają się na procesach interaktywnych w tworzeniu, dyfuzji i stosowaniu wiedzy. Systemowy charakter jest jedną z najczęściej eksponowanych cech procesów innowacyjnych zachodzących we współczesnej gospodarce. Innowacja najczęściej powstaje w wyniku współpracy i interakcji między różnymi podmiotami, jest wynikiem działania systemowego, nie indywidualnego. Systemowe podejście do innowacji, promowane jest szczególnie przez UE czy OECD (Kukliński, 1997). Podstawowe systemy innowacji, wyodrębniane i poddawane analizie, to: krajowe systemy innowacji, regionalne systemy innowacji, sektorowe systemy innowacji, systemy technologiczne czy klastry przemysłowe (Nowakowska, 2007).

Regiony są ważną areną procesów wytwarzania i transmisji innowacji (Ratti i in., 1997). Regionalny system innowacji to sieć powiązań i współpracy pomiędzy instytucjami decydującymi o społeczno-gospodarczym charakterze regionu (European Commission, 1998). Celem współdziałania tych podmiotów jest rozwój innowacyjności danego regionu przez wspieranie potencjału innowacyjnego przedsiębiorstw zgodnie z potrzebami rynku. Dzięki systemowi innowacji gospodarka regionu ma stanowić sprawny mechanizm tworzenia i dyfuzji wiedzy. Na regionalny system innowacji składają się komplementarne i współzależne podsystemy (Markowski, 2000):

- naukowo-badawczy - składają się na niego podmioty badawczo-rozwojowe, uczelnie wyższe, instytucje nauki działające w sferze innowacji i transferu technologii;

- instytucjonalny - łączy podmioty wspomagające przebieg procesów innowacyjnych (np. parki i inkubatory technologiczne, centra transferu technologii);

- produkcyjno-usługowy - utworzony przez podmioty gospodarcze zajmujące się implementowaniem nowoczesnych rozwiązań w działalności przemysłowej (zajmujące się 
działalnością technologiczno-przemysłową, wdrożeniami i komercjalizacją nowych rozwiązań);

- finansowy - składają się na niego instrumenty finansowe ułatwiające kreowanie rozwiązań innowacyjnych (np. fundusze venture capital);

- społeczno-kulturalny - stanowi układ specyficznych sposobów zachowań i cech strukturalnych typowych dla danego regionu.

Regionalny system innowacji to sieć instytucji prywatnych i publicznych, których działanie i współpraca umożliwiają wytwarzanie, adaptację, modyfikację oraz rozpowszechnianie innowacji i nowych technologii w regionie. Na jakość krajowych i regionalnych systemów innowacji duży wpływ mają poziom wykształcenia społeczeństwa oraz rozwój i jakość funkcjonowania jednostek naukowych i badawczo-rozwojowych (Borowiec, Dorocki, Jenner, 2009).

Fundamentem działania regionalnych systemów innowacji i elementem łączącym działanie poszczególnych podsystemów są władze lokalne i regionalne wraz z efektywną polityką innowacyjną, określaną przez regionalne strategie innowacji. Stanowią one „endogeniczne, oddolne procesy zorientowane w kierunku środowiska biznesu, będące działaniami nakierowanymi na długofalowe planowanie uzewnętrzniające powiązania występujące pomiędzy aktorami w dziedzinie innowacji w regionie" (European Commission, 1997). RSI to podstawowe narzędzie kształtowania polityki innowacyjnej na poziomie regionu. Celem RSI jest budowanie przewagi konkurencyjnej regionów i wzmocnienie ich zdolności wykorzystania wiedzy i innowacji, a także podnoszenie konkurencyjności MŚP przez wprowadzenie nowych technologii. Nie chodzi przy tym o implementowanie nowych, uważanych za najnowocześniejsze innowacji, ale rozwijanie i dostosowywanie do nowych warunków branż już w regionie istniejących (Wieloński, Szmigiel, 2006).

Procesy innowacyjne w gospodarce i społeczeństwie obejmują licznych uczestników w różnych instytucjach. Do instytucji wspierających procesy innowacyjne zaliczyć trzeba (RSI WM, 2008):

- instytucje tworzące innowacje, do których należą jednostki badawczo-rozwojowe, uczelnie, firmy innowacyjne;

- instytucje i firmy zajmujące się komercyjnie transferem technologii, innowacji i wiedzy oraz firmy pośredniczące w tych działaniach (firmy inżyniersko-doradcze, doradcze i szkoleniowe, biura rzeczników patentowych, kancelarie prawne itp.);

- instytucje typu non-profit powołane statutowo do wspierania innowacji.

Wśród instytucji ostatniego typu znajdują się jednostki dofinansowane ze środków publicznych, takie jak: centra transferu technologii przy uczelniach i instytutach badawczych.

Istotnym celem regionalnych systemów innowacji jest rozwój społeczno-gospodarczy regionu, osiągnięty przez budowę gospodarki opartej na wiedzy (Wieloński, Szmigiel, 2006). 


\section{RoZWÓJ SIECI WSPÓŁPRACY W MAŁOPOLSCE DZIĘKI FUNDUSZOM STRUKTURALNYM UE}

Poziom innowacyjności województwa małopolskiego można określić za pomocą różnych wskaźników, w odniesieniu zarówno do Polski, jak i innych państw. Z perspektywy całego kraju Małopolska należy do najbardziej innowacyjnych regionów. Wydatki na badania i rozwój stanowią tu ok. 0,95\% PKB, dużo powyżej średniej dla Polski, a więcej na ten cel wydawane jest jedynie w województwie mazowieckim. Według klasyfikacji Regionalnego Indeksu Innowacyjności region ten klasyfikowany jest poniżej średniej europejskiej pod tym względem (jako medium-low innovator). Struktura nakładów na B+R w zależności od źródła finansowania także daleka jest od optymalnej.

Tab. 1. Struktura nakładów na B+R (w \%) w zależności od źródła finansowania (2008)

\begin{tabular}{|l|c|c|c|c|}
\hline Kraj/Region & $\begin{array}{c}\text { Sektor } \\
\text { przedsiębiorstw }\end{array}$ & Rząd & $\begin{array}{c}\text { Szkolnictwo } \\
\text { wyższe }\end{array}$ & Inne \\
\hline UE-27 & 63 & 13 & 23 & 1 \\
\hline Polska & 31 & 35 & 34 & - \\
\hline Małopolska & 29 & 24 & 46 & 1 \\
\hline
\end{tabular}

Źródło: Eurostat, http://epp.eurostat.ec.europa.eu (dostęp 15.06.2013)

Regiony mają zasadnicze znaczenie w rozwoju gospodarki opartej na wiedzy. W województwie małopolskim występuje bardzo silna koncentracja instytucji wsparcia innowacyjnego biznesu (Godowska, 2012). Małopolska jest stosunkowo silnym gospodarczo regionem, zlokalizowanych jest tu wiele przedsiębiorstw. Stanowi także silny ośrodek akademicki, drugi pod względem wielkości po województwie mazowieckim w Polsce. Siłę powiązań między instytucjami akademickimi a przedsiębiorstwami i środowiskami rządowo-administracyjnymi obrazuje model potrójnej helisy. Współpraca międzysektorowa, najczęściej interpretowana jako współpraca na rzecz wdrażania wiedzy i innowacji, coraz częściej uzupełniana jest o wspólne tworzenie profilu absolwenta, a także wspólne określanie kierunków nauczania (Górniak i in., 2009: 127).

Koncepcja potrójnej helisy jako propozycja podejścia do programowania rozwoju regionalnego została uwzględniona przy formułowaniu założeń Małopolskiego Regionalnego Programu Operacyjnego, współfinansowanego przez Europejski Fundusz Rozwoju Regionalnego. Cel działania 2.2 MRPO określono jako: „zwiększenie poziomu innowacyjności i konkurencyjności firm poprzez uaktywnienie ich współpracy z szerokim zapleczem instytucjonalnym w sferze nauki, prac badawczo-rozwojowych oraz transferu technologii”. Cel ten wpisuje się zatem w koncepcję trójstronnej współpracy na rzecz kreowania środowiska odpowiedniego dla wzrostu innowacyjności i konkurencyjności.

Do marca 2011 roku w województwie małopolskim odnotowano powstanie 15 inicjatyw klastrowych. W większości mają one krótką historię, gdyż zostały powołane do życia w latach 2008-2011. System wsparcia rozwoju klastrów stanowi Plan Wspierania Klastrów w Województwie Małopolskim (PWK, 2009). Zakłada on ukierunkowanie wydatków 
publicznych z funduszy strukturalnych na wsparcie klastrów cechujących się istotnym udziałem w gospodarce regionu, wysoką dynamiką wzrostu i konkurencyjnością. Należałoby jednak dokładnie zbadać, na ile klastry kształtują się z chęci pozyskania środków UE na tego typu inicjatywy, a na ile rzeczywiście jako potrzeba budowania tego rodzaju współpracy. Niepokojące jest to, że wiele z nich nie jest w stanie przeznaczyć żadnych środków na realizację wspólnych projektów. Brak także zależności pomiędzy poziomem innowacyjności branży klastra a wysokością przyznanych zewnętrznych środków finansowych (Deloitte Business Consulting S.A, 2010). Powoduje to, że aktywność klastrów w zdecydowanej mierze uzależniona jest od dostępności dotacji publicznych.

Zasoby województwa małopolskiego pozwalają na budowę regionalnego systemu innowacji. Na tę swoistą sieć innowacji składają się różnego typu instytucje, działania, zasoby oraz łączące je powiązania. Do tworzących system innowacji instytucji należy zaliczyć działające już i powstające dopiero przedsiębiorstwa, uczelnie i instytuty naukowe oraz władze regionalne. Celem współdziałania tych podmiotów jest rozwój innowacyjności regionu przez wspieranie potencjału innowacyjnego przedsiębiorstw zgodnie z potrzebami rynku. Dzięki systemowi innowacji gospodarka regionu ma stanowić sprawny mechanizm tworzenia i dyfuzji wiedzy. Podstawą dla budowy regionalnego systemu innowacji w województwie małopolskim jest Regionalna Strategia Innowacji Województwa Małopolskiego 2008-2013.

RSI ma na celu stymulowanie rozwoju innowacji w małopolskich firmach, w szczególności przez uaktywnienie ich współpracy z jednostkami naukowymi. Koncentruje się ona na wskazaniu celów strategicznych i taktycznych, a także konkretnych działań, których realizacja ma się przyczynić do wzrostu poziomu innowacyjności Małopolski. Jako podstawowe źródło finansowania tych działań wskazane są fundusze strukturalne UE.

Fundusze strukturalne Unii Europejskiej są zatem istotnym czynnikiem wspierania sieci współpracy w regionie małopolskim. Jako podstawowe źródła finansowania celów Regionalnej Strategii Innowacji wskazano: Małopolski Regionalny Program Operacyjny, Program Operacyjny Innowacyjna Gospodarka (współfinansowane przez Europejski Fundusz Rozwoju Regionalnego) oraz Program Operacyjny Kapitał Ludzki (współfinansowany przez Europejski Fundusz Społeczny). Dzięki tym samym programom możliwe jest uzyskanie wsparcia na rozwój powiązań w ramach potrójnej helisy i klastrów. Podsumowanie możliwości w tym zakresie przedstawiono w tabeli 2.

Zgodnie z misją RSI województwa małopolskiego strategia ta ma umożliwić zwiększenie poziomu innowacyjności i konkurencyjności firm przez uaktywnienie ich współpracy z szerokim zapleczem instytucjonalnym w sferze nauki, prac badawczo-rozwojowych oraz transferu technologii (RSI WM, 2008-2013: 22). Współpraca ta ma być rozwijana w ramach sieci współpracy, które pozwalają efektywniej wykorzystać potencjał tworzących je partnerów. 
Tab. 2. Źródła finansowania sieci współpracy ze środków funduszy strukturalnych UE 2007-2013 w województwie małopolskim

\begin{tabular}{|c|c|}
\hline Program/ działanie & Obszary wsparcia \\
\hline \multicolumn{2}{|c|}{ Małopolski Regionalny Program Operacyjny } \\
\hline $\begin{array}{l}\text { Działanie 2.1. Rozwój i podnie- } \\
\text { sienie konkurencyjności przedsię- } \\
\text { biorstw }\end{array}$ & $\begin{array}{l}\text { Wspólne przedsięwzięcia i tworzenie powiązań kooperacyjnych } \\
\text { pomiędzy przedsiębiorstwami, w tym tworzenie klastrów }\end{array}$ \\
\hline $\begin{array}{l}\text { Działanie 2.2. Wsparcie } \\
\text { komercjalizacji badań } \\
\text { naukowych }\end{array}$ & $\begin{array}{l}\text { Promowanie współpracy oraz tworzenia powiązań pomiędzy } \\
\text { gospodarką a strefą naukową przez dofinansowanie wspólnych } \\
\text { przedsięwzięć badawczych oraz podniesienie poziomu innowa- } \\
\text { cyjności w przedsiębiorstwach, dzięki realizacji projektów in- } \\
\text { westycyjnych z zakresu B+R }\end{array}$ \\
\hline $\begin{array}{l}\text { Działanie 5.1. Krakowski Obszar } \\
\text { Metropolitarny jako ważny węzeł } \\
\text { europejskiej przestrzeni badawczej }\end{array}$ & $\begin{array}{l}\text { Wzmocnienie Krakowskiego Obszaru Metropolitarnego jako } \\
\text { prężnego ośrodka naukowo-badawczego oraz centrum nowo- } \\
\text { czesnej i innowacyjnej gospodarki. Celem działania jest m.in. } \\
\text { dążenie do konsolidacji środowisk naukowych działających na } \\
\text { terenie KOM i stworzenie małopolskiego ośrodka innowacji }\end{array}$ \\
\hline \multicolumn{2}{|c|}{ Program Operacyjny Innowacyjna Gospodarka } \\
\hline $\begin{array}{l}\text { Działanie 1.3. Wsparcie projektów } \\
\text { B+R na rzecz przedsiębiorców } \\
\text { realizowanych przez jednostki na- } \\
\text { ukowe }\end{array}$ & $\begin{array}{l}\text { Wsparcie wykorzystania w praktyce gospodarczej wyników } \\
\text { prac B+R prowadzonych w polskich jednostkach naukowych, } \\
\text { w szczególności realizacja projektów rozwojowych prowadzo- } \\
\text { nych na potrzeby danej branży/ gałęzi gospodarki lub o szcze- } \\
\text { gólnym wymiarze społecznym }\end{array}$ \\
\hline $\begin{array}{l}\text { Działanie 5.1. Wspieranie rozwoju } \\
\text { powiązań kooperacyjnych o zna- } \\
\text { czeniu ponadregionalnym }\end{array}$ & $\begin{array}{l}\text { Wzmocnienie pozycji konkurencyjnej przedsiębiorstw przez } \\
\text { rozwój powiązań pomiędzy przedsiębiorstwami oraz pomiędzy } \\
\text { przedsiębiorstwami a instytucjami otoczenia biznesu }\end{array}$ \\
\hline \multicolumn{2}{|c|}{ Program Operacyjny Kapitał Ludzki } \\
\hline $\begin{array}{l}\text { Działanie 2.1. Rozwój kadr nowo- } \\
\text { czesnej gospodarki }\end{array}$ & $\begin{array}{l}\text { Działania/ projekty realizowane na rzecz klastrów - projekty } \\
\text { systemowe PARP }\end{array}$ \\
\hline $\begin{array}{l}\text { Działanie } 4.1 \text { Wzmocnienie i roz- } \\
\text { wój potencjału dydaktycznego } \\
\text { szkolnictwa wyższego }\end{array}$ & $\begin{array}{l}\text { Budowa potencjału rozwojowego uczelni przez umożliwienie im } \\
\text { rozszerzenia i wzbogacenia oferty edukacyjnej oraz zapewnienie } \\
\text { efektywnego zarządzania systemem szkolnictwa wyższego oraz } \\
\text { dostosowanie struktury podaży absolwentów do potrzeb gospo- } \\
\text { darki (m.in. w formie współpracy z przedsiębiorstwami) }\end{array}$ \\
\hline $\begin{array}{l}\text { Działanie 4.2. Rozwój kwalifikacji } \\
\text { kadr systemu B+R i wzrost świado- } \\
\text { mości roli nauki w rozwoju } \\
\text { gospodarczym }\end{array}$ & $\begin{array}{l}\text { Podniesienie kompetencji kadr systemu B+R do poziomu za- } \\
\text { pewniającego efektywną współpracę jednostek naukowych } \\
\text { i przedsiębiorstw w zakresie wdrażania osiągnięć naukowych } \\
\text { w gospodarce }\end{array}$ \\
\hline Działanie 8.2. Transfer wiedzy & $\begin{array}{l}\text { Promowanie współpracy sfery nauki i przedsiębiorstw przez } \\
\text { organizację staży i szkoleń praktycznych dla pracowników, po- } \\
\text { moc naukowcom przy zakładaniu własnych firm, propagowa- } \\
\text { nie tworzenia sieci współpracy i wymiany informacji. Ponadto } \\
\text { w ramach działania realizowane są projekty dotyczące rozwoju } \\
\text { sieci współpracy i wymiany informacji między naukowcami } \\
\text { a przedsiębiorcami w zakresie innowacji i transferu technologii } \\
\text { na poziomie regionalnym i lokalnym }\end{array}$ \\
\hline
\end{tabular}

Źródło: opracowanie własne na podstawie dokumentów programowych (programy operacyjne) wdrażanych w Polsce w latach 2007-2013 
Tworzenie sieci powiązań jest jednym z celów horyzontalnych RSI WM. Pogłębienie współpracy uczelnia - przedsiębiorstwo ma nastąpić dzięki:

- realizacji programu zamawianych przez przedsiębiorstwa prac magisterskich i doktorskich,

- realizacji programu staży pracowników naukowo-badawczych w przedsiębiorstwach oraz pracowników MŚP w jednostkach naukowo-badawczych,

- utworzeniu systemu badań edukacji i rynku pracy w celu dostosowania programów kształcenia do wymagań rozwoju innowacyjnej gospodarki regionu.

Z kolei wzmocnienie kontaktów sieciowych instytucji związanych z innowacyjnością regionu i lepsze wykorzystanie ich potencjału ma nastąpić przez: rozwój i wsparcie inicjatyw klastrowych, rozwój i wsparcie inicjatyw międzyuczelnianych o charakterze badawczo-rozwojowym oraz stworzenie efektywnego systemu kształcenia podstawowego i specjalistycznego w Małopolsce.

W celu efektywnego wsparcia regionalnych systemów innowacji i poprawienia poziomu innowacyjności regionu w tworzonych strategiach rozwoju regionalnego uwzględnia się formę współpracy, jaką stanowią klastry, istotnie przyczyniające się do rozwoju danego regionu. Klastry można uznać za jeden z kluczowych elementów rozwoju regionalnych systemów innowacji.

\section{ZAKOŃCZENIE}

Sprawnie funkcjonująca sieć powiązań i współpracy między władzą publiczną, jednostkami naukowymi i przedsiębiorstwami jest niezbędna, aby stworzyć region wiedzy i innowacji. Taka struktura, finansowana z różnych źródeł, w tym z funduszy strukturalnych UE, ma szanse powodzenia i stania się obszarem innowacyjnym i konkurencyjnym.

Władze regionalne, przedsiębiorstwa i uczelnie wyższe Małopolski zdają się dostrzegać te szanse. Coraz częściej i chętniej współpracują ze sobą, korzystają ze wsparcia unijnych funduszy, wpływając tym samym na innowacyjność regionu oraz budowanie gospodarki opartej na wiedzy. Konkretne rezultaty tych działań będzie można jednak ocenić dopiero za kilka lat, kiedy skończy się obecna perspektywa finansowa unijnego budżetu i sfinalizowana zostanie realizacja tych programów współfinansowanych z funduszy strukturalnych w Polsce, które umożliwiają wsparcie rozwoju sieci współpracy w regionie.

\section{Literatura}

Babiak, J. (red.) (2008). Fundusze Europejskie a innowacyjność polskiej gospodarki. Warszawa: Wydawnictwo Studio Emka.

Borowiec, M., Dorocki, S., Jenner, B. (2009). Wpływ zasobów kapitału ludzkiego na kształtowanie społeczeństwa informacyjnego i innowacyjności struktur przemysłowych. Prace Komisji Geografii Przemystu Polskiego Towarzystwa Geograficznego, 13, 95-109. 
Ceglie, G., Dini, M. (1999). SME Cluster and Network Development in Developing Countries: The Experience of UNIDO. Vienna: United Nations Industrial Development Organization.

Clark, B. R. (1998). Creating Entrepreneurial Universities: Organisational Pathways of Transformation, Oxford-New York: Published for the IAU Press by Pergamon Press.

Deloitte Business Consulting S.A. (2010). Benchmarking klastrów w Polsce - 2010. Raport z badania, Warszawa: Polska Agencja Rozwoju Przedsiębiorczości.

Etzkowitz, H., Leydesdorff, L. (2000). The Dynamics of Innovation: From National Systems and "Mode 2" to a Triple Helix of University-Industry-Government Relations. Research Policy, 29, $109-123$.

European Commission (1997). DG Regio, DG Enterprise. RIS Practical Guide.

European Commission (1998). Regional Innovation Systems: Designing for the Future - REGIS. Final Report Coordinated by: Philip Cooke, DG XII - Science, Research and Development.

Gierańczyk, W. (2010). Rola własności intelektualnej w budowaniu innowacyjności krajów Unii Europejskiej. Prace Komisji Geografii Przemystu Polskiego Towarzystwa Geograficznego, 16, 76-86.

Główny Urząd Statystyczny (2011). Regiony Polski. Warszawa.

Godowska, M. (2012). Region uczący się - uwarunkowania i determinanty rozwoju na przykładzie województwa małopolskiego. Przedsiębiorczość - Edukacja, 8, 278-286.

Golejewska, A. (2012). Innowacyjność a konkurencyjność regionalna krajów Grupy Wyszehradzkiej w latach 1999-2008. Prace Komisji Geografii Przemystu Polskiego Towarzystwa Geograficznego, $19,93-115$.

Gorzelak, G., Bąkowski, A., Kozak, M., Olechnicka, A. (2006). Polskie Regionalne Strategie Innowacji: ocena $i$ wnioski dla dalszych działań. Warszawa: Ministerstwo Rozwoju Regionalnego.

Górniak, J., Jelonek, M., Kwinta-Odrzywołek, J., Skrzyńska, J., Uhl, H. (2009). Ocena wpływu projektów zrealizowanych dzięki funduszom europejskim przez uczelnie wyższe z terenu województwa małopolskiego na wzrost konkurencyjności gospodarczej regionu oraz wzmocnienie potencjatu sektora badawczo-nankowego w województwie. Kraków: Centrum Ewaluacji i Analiz Polityk Publicznych UJ.

Główny Urząd Statystyczny (2011). Regiony Polski. Warszawa.

Hollanders, H., Tarantola, S., Loschky, A. (2009). Regional Innovation Scoreboard (RIS) 2009, Pro Inno Europe, December 2009, http://www.proinno-europe.eu/

Klamut, M. (red.) (2011). Konkurencyjność i spójność w polityce rozwoju Unii Europejskiej. Wrocław: Wydawnictwo Uniwersytetu Ekonomicznego we Wrocławiu.

Kładź, K., Kowalski, A.M. (2010). Rozwój klastrów przemysłowych w Polsce. W: M.A. Weresa (red.), Polska. Raport o konkurencyjności. Klastry przemysłowe a przewagi konkurencyjne. Warszawa: Szkoła Główna Handlowa w Warszawie.

Komisja Europejska (2006). Wykorzystanie wiedzy w praktyce: Szeroko zakrojona strategia innowacyjna dla UE, COM (2006) 502 wersja ostateczna.

Komisja Europejska (2008). The Concept of Clusters and Cluster Policies and Their Role for Competitiveness and Innovation: Main Statistical Results and Lessons Learned, Commission Staff Working Document SEC (2008) 2637.

Kukliński, A. (1997). Regionalne systemy innowacji (RSI) w Polsce. Doświadczenia i perspektywy. W: A. Kukliński (red.), Problematyka przestrzeni europejskiej. Warszawa: EUROREG.

Lundvall, B.-A. (ed.) (1992). National Systems of Innovation: Towards a Theory of Innovation and Interactive Learning. London: Pinter Publishers. 
Markowski, T. (2000). Regionalne systemy innowacji w aspekcie strategii rozwoju regionalnego Polski 2000-2006. W: J. Szlachta (red.), Narodowa Strategia Rozwoju. Biuletyn KPZK PAN, 191.

Marszałek, A. (2010). Rola uczelni w regionie. Warszawa: Difin.

Ministerstwo Gospodarki (2006). Kierunki zwiększania innowacyjności gospodarki na lata 2007-2013, dokument strategiczny przyjęty przez Radę Ministrów w dniu 4 września 2006 r.

Nelson, R. (1993). National Innovation Systems. Oxford: Oxford UP.

Nowak, P. (2012). Poziom innowacyjności polskiej gospodarki na tle krajów UE. Prace Komisji Geografii Przemystu Polskiego Towarzystwa Geograficznego, 19, s. 142-152.

Nowakowska, A. (2007). Innowacje i transfer technologii. Stownik pojęć. Stowarzyszenie Organizatorów Ośrodków Innowacji i Przedsiębiorczości w Polsce (SOOIPP), PARP.

Okoń-Horodyńska, E. (red.) (2004). Rola polskiej nauki we wzroście innowacyjności gospodarki. Warszawa: Wydawnictwo Polskiego Towarzystwa Ekonomicznego.

Olechnicka, A. (2007). Innowacyjność polskich regionów. W: G. Gorzelak (red.), Polska regionalna i lokalna w świetle badań EUROREG-u. Warszawa: Wydawnictwo Naukowe Scholar.

Pachura, P. (2009). Analiza potencjału budowy efektywnych struktur transgranicznych sieci innowacyjnych na przykładzie województwa śląskiego oraz regionów Czech i Słowacji. Częstochowa. Pozyskano z: http://www.ewaluacja.gov.pl/Wyniki/Dokuments/_059.pdf (dostęp 15.06.2013).

Plan Wspierania Klastrów w Województwie Małopolskim (PWK) (2009). Opracowany przez Krakowski Park Technologiczny.

Porter, M. (2001). Porter o konkurencji. Warszawa: PWE.

Ratti, R., Bramanti, A., Gordon, R. (red.) (1997). The Dynamics of Innovative Regions. Ashgate: Aldershot.

Regionalna Strategia Innowacji Województwa Małopolskiego (RSI WM) 2008-2013. Załącznik do Uchwały Zarządu Województwa Małopolskiego nr 831/08 z dnia 18 września 2008 r., Kraków, sierpień 2008.

Sölvell, Ö., Lindqvist, G., Ketels, Ch. (2006). Zielona Księga Inicjatyw Klastrowych. Inicjatywy Klastrowe w gospodarkach rozwijajacych się i w fazie transformacji. Polska Agencja Rozwoju Przedsiębiorczości.

Wieloński, A., Szmigiel, K. (2006). Regionalne Strategie Innowacji jako czynnik aktywizacji polskiej przestrzeni przemysłowej. Prace Komisji Geografii Przemystu Polskiego Towarzystwa Geograficznego, 9, 20-27.

Dorota Murzyn, dr, Uniwersytet Pedagogiczny w Krakowie, Instytut Politologii.

Doktor nauk humanistycznych w zakresie nauk o polityce, magister ekonomii, adiunkt w Instytucie Politologii Uniwersytetu Pedagogicznego w Krakowie (Katedra Ekonomii i Polityki Gospodarczej). Zainteresowania badawcze: polityka gospodarcza, integracja europejska, polityka spójności UE. Członek Regional Studies Association, Seaford, UK.

Dorota Murzyn, PhD in Political Science, MA in Economics, Senior Lecturer at the Institute of Political Science, Pedagogical University of Cracow (Department of Economics and Economic Policy). Research interests: economic policy, European integration, EU cohesion policy. Member of Regional Studies Association, Seaford, UK.

adres/address: Uniwersytet Pedagogiczny w Krakowie, Instytut Politologii

ul. Podchorążych 2, pok. 224, 30-084 Kraków, Polska

e-mail:mdorota@up.krakow.pl 